Agro-Science Journal of Tropical Agriculture, Food, Environment and Extension Volume 8 Number 1 January 2009 pp. 14-19

ISSN 1119-7455

\title{
FERTILITY ASSESSMENT OF SOME INLAND DEPRESSION AND FLOODPLAIN (WETLAND) SOILS IN AKWA IBOM STATE
}

\author{
Udo Bassey, U. Utip, Kufre E. Inyang, Monday T and. Idungafa, Monday A \\ Department of Agricultural Technology, Akwa Ibom State College of Agriculture, Obio Akpa, P.M. \\ B. 1001, Abak, Nigeria.
}

\begin{abstract}
The constraints to crop production of some inland depression and floodplain (wetland) soils in Akwa Ibom State were assessed. The aim was to identify soil parameters that limit crop production in these soils. Three locations, Ikot Obio Inyang (Ikg), Ikot Idio (Ikd) and Ibiaku Ikot Obong (Bku), were used for the inland depression while Ibiaku Uruan (Ibk), Usuk Inyang Idoro (Usg) and Iwok (Iwk) were used for the floodplain soils. One profile pit was dug in each location making a total of six profile pits. Soil samples were collected according to their genetic horizons for laboratory analysis. Fertility Capability Classifica tion (FCC) system was used to assess the soil quality. The results indicated that gleying (g), low potassium reserve $(k)$ and acidic reaction (h) were the general constraints of these soils. Also, Ikg and Ikd of inland depression soils had sandy (S) top soils while Bku had loamy top $(L)$ soils but the three sub soils were loamy $(L)$. All the floodplain soils had sandy (S) soils at both top and subsoils. For effective management of these soils, application of organic manure (including cattle manure) would supply the basic cations including $\mathrm{K}$, as well as reduce soil acidity.
\end{abstract}

Keywords: Fertility assessment, inland depression, floodplain, Fertility Capability Classification (FCC)

\section{INTRODUCTION}

The rate at which the world's population is growing should be a major concern for everyone. According to the United Nations Population Division (1996), the world's population is increasing by about 1 billion people every 12 years. In 2020, the population is projected to be about 8 billion. Increased resources are required for meeting the demands of this growing population, especially in the developing countries. Arable land for increased food production is a very important resource to be considered. Spiertz and Rabbinge (1999) for instance, noted that food security is a first priority for poor people.

Land that is suitable for agricultural production is finite and vulnerable resource. Already, there is widespread decline in the yields of most crops. This is because, poverty and the need to produce more food, the change in land use and farming practices have resulted in soil organic matter depletion, nutrient mining and soil degradation (Van and Breman, 1990 and de Jager et al., 1998).

Similarly, Onyekwere et al.. (2001) observed that apart from the scarcity of upland soils for agriculture, the few available cultivated soils which used to be fertile, have become severely degraded by continuous cropping practiced now with high population. Now, it is quite obvious that an indispensable sector of economy (agriculture) is facing serious constraints of scarcity of land and decline in soil fertility. This could underscore why we are having the current global food crisis. It is absolutely imperative that pragmatic steps must be taken to serve mankind from an impending danger of more serious famine.

These striking problems affecting mankind could be alleviated through efficient management of soils and continuous expansion of available cropping into wetland soils. One way of managing soil efficiently is the appropriate use of fertilizers. Farmers should avoid 'fertilizer abuse', a situation whereby fertilizer is applied indiscriminately without a pre-soil test to determine the specific needs of the soil. This practice is not in the best interest of sustainable agricultural development because excess application of fertilizer will not only lead to the waste of the products but more seriously to reduction in crop yield because of nutrient antagonism (Uniuyo Consult Ltd, 2003). Also, with soil testing, nutrient values below the critical limits could be supplemented as the utility of all inputs will be rendered useless or made inefficient if there is nutrient imbalance (Katyal, 2004). Moreso, there is need for farmers to know the health of the soils by monitoring nutrients status through soil and plant tissue tests as farmers may not know the hidden hunger which exist (Dar, 2004).

Apart from the soil and plant test which can give the basis for efficient soil management, another drastic measure to increase food production 
according to Eshiet (1994) is the expansion of arable cropping into the wetlands soils especially in Akwa Ibom State which is known to have one of the highest population densities in the country (Edem et al., 1998).

Guthrie, (1985) looked at wetland soils as having great potentials for sustainable increase in food production because of their inherent high fertility status and their occurrence in the flat or near flat landscapes where soil erosion is not a major constraint to crop production.

In his evaluation of wetland soils in Akwa Ibom State for maize production, Udo (2007) observed that these soils are suitable for the crops. The soils of wetland have received over-whelming acceptance for agriculture and other uses although Ogban and Ibia (1998) noted that little studies have been made on wetlands and are under utilized. Udo et a.l, (2008) suggested that this might be as a result of their complexities in chemical properties, which are the major determinants of nutrients status of soils. Aquic moisture regime is a characteristic of wetland soils, this makes them chemically dynamic; as such need regular testing of properties to avoid a situation whereby a wrong soil management practice is imposed upon the soils.

The study was therefore made to assess the constraints of wetland soils in Akwa Ibom State for efficient soil management in sustainable agriculture.

\section{MATERIALS AND METHODS}

This study was conducted in Akwa Ibom State in South Eastern Nigeria. The area lies between latitudes $4^{0} 30^{\prime}$ and $5^{0} 30^{\prime}$ North and longitudes $7^{0} 30^{\prime}$ and $8^{0} 30^{\prime} \mathrm{E}$. in the forest zone with a mean annual rainfall of over $2500 \mathrm{~mm}$. The areas have relatively high temperature values with the mean annual temperature ranging from $26-28^{\circ} \mathrm{C}$.

The soils are mainly formed from alluvial and colluvial deposits. Six soil profiles dug at Ikot Obio Inyang (Ikg), Ikot Idio (Ikd) and Ibiaku Ikot Obong (Bku) for inland depression soils and at Ibiaku Uruan (Ibk), Usuk Inyang Idoro (Usg) and Iwok (Iwk) for floodplain soils were used. Samples were collected according to their genetic horizons. The samples collected were air-dried, sieved $(<2 \mathrm{~mm})$ and used for laboratory analysis.

Particle size analysis was determined by hydrometer method of Bouyoucous (1951) using calgon as a dispersing agents as described by Day (1965). Soil pH was determined in 1:1 soil water suspension using $\mathrm{pH}$ meter with glass electrode. Exchangeable bases were extracted with 1 normal $\mathrm{NH}_{4} \mathrm{OAC}$, and the cations: $\mathrm{Ca}$ and $\mathrm{Mg}$ were determined by EDTA titration of Jackson (1962) while $\mathrm{K}$ and $\mathrm{Na}$ were by the use of flame photometer. Exchangeable acidity was extracted with $1 \mathrm{~N} \mathrm{KCl}$ solution. The exchangeable acidity and aluminum were determined by the titration as described by Juo, 1975. Organic carbon was determined by the dichromate wet oxidation method of Walkley and Black (1935) as described by Udo and Ogunwale (1986). The value was multiplied by 1.73 to obtain organic matter. Available phosphorus was determined by Bray - 1 method of Bray and Kurtz (1945). Total Nitrogen was determined by the microkjeldahl digestion and distillation method as described by Udo and Ogunwale (1986). Effective Cation Exchange Capacity (ECEC) was obtained by the summation of exchangeable bases and acidity $\left(\mathrm{Ca}^{2}+\mathrm{Mg}^{2+}+\mathrm{Na}^{+}+\mathrm{K}^{+}+\mathrm{EA}\right)$.

Base Saturation (BS) was calculated from the formula:

$$
\mathrm{BS}=\frac{\mathrm{Ca}^{2+}+\mathrm{Mg}^{2+}+\mathrm{K}^{+}+\mathrm{Na}^{+}}{\mathrm{ECEC}} \times \underline{100}
$$

\section{Evaluation Methods}

Evaluation of these soils for fertility constraints was done using Fertility Capability Classification (FCC) system. Though developed for upland soils, FCC was extended for wetland soils by Sanchez and Boul (1985). The system (FCC) appears to be a suitable framework for agronomic soil taxonomy, one which is acceptable to both pedologists, and agronomists (Lin, 1989).

It is a technical system of grouping soils, which have similar limitations, and management problems in terms of the nutrient supply capacity of the soils. The system consists of three classification levels: Type (topsoil texture), substrata type (subsoil texture) and condition modifiers or fertility constraints. The FCC unit is formed by the combination of the class designation from the three classification levels.

\section{RESULTS AND DISCUSSION}

The results of the soil analysis are presented in Tables 1 and 2 while the FCC units of the soils studied are presented in Table 3 .

The result of FCC of inland depression soils indicated that two locations (Ikg and Ikd) were classified as SLgkh while Bku was classified as Lgkh. This implies that both Ikg and Ikd were characterized by sandy (S) topsoils and loamy (L) subsoils. Bku had both top and subsoils as loamy. All the three locations had the same constraints of gleying $(\mathrm{g})$, low potassium reserve $(\mathrm{k})$ and acidic reaction $(h)$.

The results of FCC units of flood plain soils as shown on Table 3 indicated that the three locations Ibk, Usg and Iwk were all classified as Sgkh. This implies that the three locations have sandy (S) soils at both top and subsoils. The soils also have constraints of gleying $(\mathrm{g})$, low potassium reserve $(\mathrm{k})$ and acidic reaction $(\mathrm{h})$. 
Table 1: Some Characteristics of Inland Depression Soils Studied

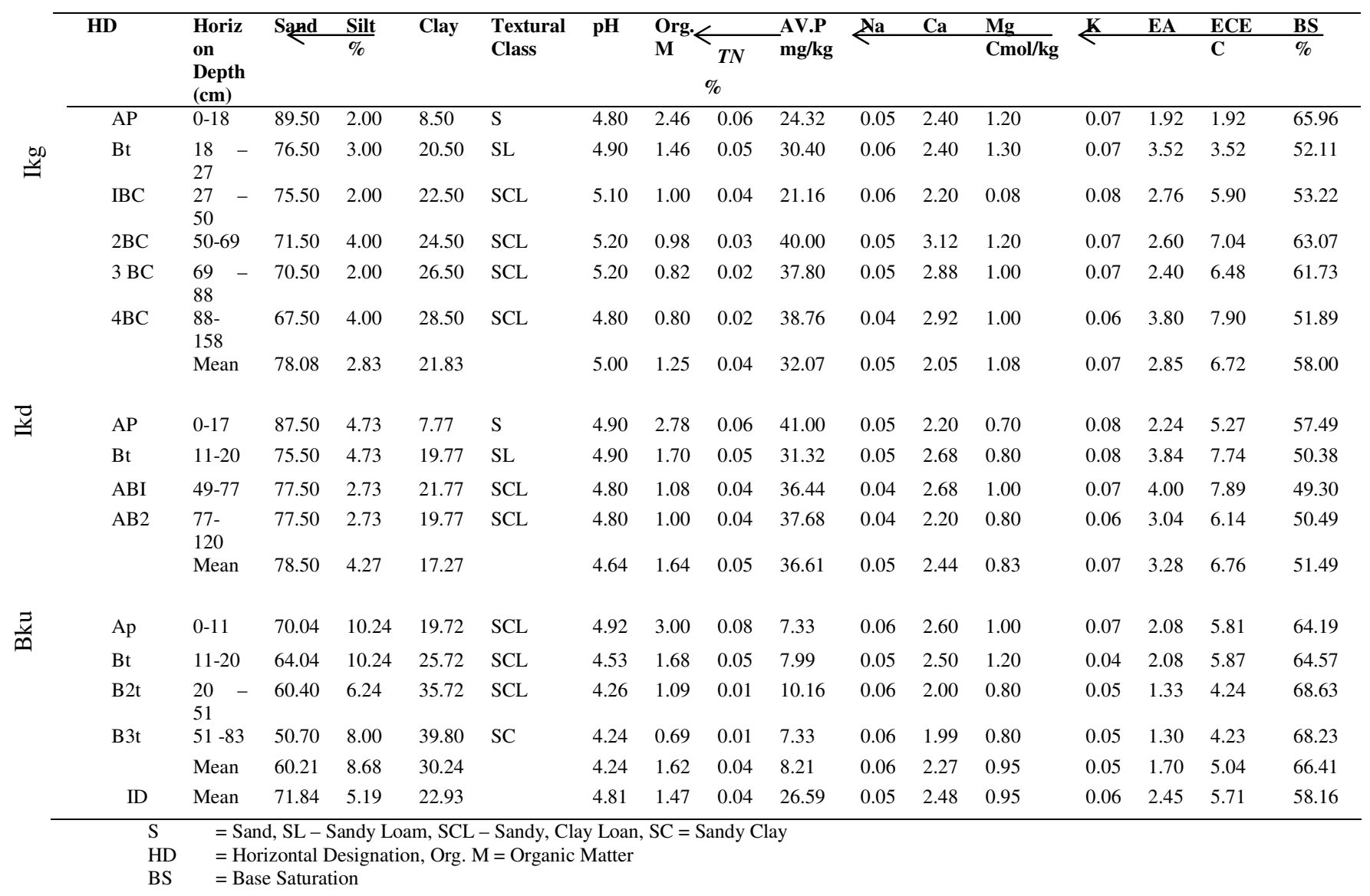

Table 2: Some Characteristics of Floodplain Soils Studied

\begin{tabular}{|c|c|c|c|c|c|c|c|c|c|c|c|c|c|c|c|c|c|}
\hline & HD & $\begin{array}{l}\text { Horizon } \\
\text { Depth } \\
\text { (cm) }\end{array}$ & Sand & $\frac{\text { Silt }}{\%}$ & Clay & $\begin{array}{l}\text { Texyural } \\
\text { Class }\end{array}$ & pH & $\begin{array}{l}\text { Org. } \\
\text { M }\end{array}$ & $\underset{T N}{\longleftarrow}$ & $\begin{array}{l}\text { AV.P } \\
\mathrm{mg} / \mathrm{kg}\end{array}$ & 些 & $\mathrm{Ca}$ & $\frac{\mathrm{Mg}}{\mathrm{Cmol} / \mathrm{kg}}$ & $\mathbf{K}$ & EA & ECEC & $\underset{\%}{\mathrm{BS}}$ \\
\hline \multirow{8}{*}{ 光 } & AP & $0-15$ & 88.84 & 5.94 & 5.22 & $\mathrm{~S}$ & 4.81 & 3.53 & 0.09 & 21.99 & 0.09 & 3.12 & 1.00 & 0.08 & 2.08 & 6.37 & 67.35 \\
\hline & $\mathrm{Bt}$ & $15-23$ & 88.84 & 5.94 & 5.22 & S & 5.10 & 1.31 & 0.04 & 22.66 & 0.09 & 3.60 & 1.20 & 0.05 & 3.38 & 8.30 & 59.52 \\
\hline & IBC & $23-34$ & 94.84 & 2.58 & 2.58 & S & 5.76 & 1.93 & 0.03 & 9.33 & 0.08 & 1.92 & 1.00 & 0.05 & 1.76 & 4.81 & 63.41 \\
\hline & $2 \mathrm{BC}$ & $34-50$ & 88.84 & 5.94 & 5.22 & S & 5.63 & 1.00 & 0.03 & 9.33 & 0.04 & 4.80 & 2.10 & 0.04 & 1.80 & 8.81 & 79.57 \\
\hline & $3 \mathrm{BC}$ & $50-68$ & 88.84 & 7.22 & 7.22 & S & 5.70 & 0.99 & 0.03 & 36.60 & 0.08 & 4.00 & 2.10 & 0.04 & 3.04 & 9.26 & 67.17 \\
\hline & & Mean & 89.84 & 5.09 & 5.09 & & 5.40 & 1.61 & 0.04 & 13.73 & 0.08 & 3.49 & 1.48 & 0.05 & 2.41 & 6.27 & 67.41 \\
\hline & $\mathrm{AP}$ & $0-18$ & 84.84 & 7.94 & 7.22 & S & 5.40 & 2.25 & 0.07 & 3.33 & 0.10 & 2.88 & 1.00 & 0.07 & 19.8 & 23.85 & 16.77 \\
\hline & $\mathrm{Bt}$ & $18-39$ & 76.84 & 9.94 & $\begin{array}{l}13.2 \\
2\end{array}$ & LS & 4.16 & 2.21 & 0.06 & 7.33 & 0.11 & 1.92 & 1.60 & 0.07 & $\begin{array}{l}26.6 \\
0\end{array}$ & 29.80 & 10.74 \\
\hline \multirow{3}{*}{$\begin{array}{l}\infty \\
\infty \\
\infty\end{array}$} & $\mathrm{ABI}$ & $39-87$ & 70.84 & $\begin{array}{l}11.9 \\
4\end{array}$ & $\begin{array}{l}17.2 \\
2\end{array}$ & SL & 4.20 & 2.11 & 0.05 & 2.66 & 0.11 & 3.60 & 1.20 & 0.08 & $\begin{array}{l}26.0 \\
0\end{array}$ & 30.90 & 16.10 \\
\hline & $\mathrm{AB} 2$ & $87-198$ & 82.84 & $\begin{array}{l}4 \\
7.74\end{array}$ & 9.20 & LS & 4.36 & 1.97 & 0.06 & 5.33 & 0.11 & 1.20 & 0.70 & 0.10 & $\begin{array}{l}21.8 \\
0\end{array}$ & 23.91 & 8.82 \\
\hline & & Mean & 78.84 & 9.39 & $\begin{array}{l}11.7 \\
2\end{array}$ & & 4.49 & 2.15 & 0.06 & 4.66 & 0.11 & 2.35 & 1.13 & 0.08 & $\begin{array}{l}23.7 \\
0\end{array}$ & 27.14 & 13.11 \\
\hline \multirow[t]{7}{*}{$\underline{3}$} & Ap & $0-14$ & 86.84 & 5.94 & 7.22 & S & 4.73 & 3.32 & 0.10 & 29.99 & 0.09 & 2.40 & 1.00 & 0.13 & 4.00 & 7.62 & 47.57 \\
\hline & $\mathrm{Bt}$ & $14-32$ & 82.84 & 9.94 & 7.22 & LS & 4.52 & 1.64 & 0.04 & 30.66 & 0.09 & 3.60 & 1.10 & 0.06 & 4.80 & 9.55 & 49.74 \\
\hline & B $2 t$ & $32-57$ & 88.84 & 5.94 & 5.22 & $\mathrm{~S}$ & 4.53 & 3.01 & 0.09 & 39.99 & 0.09 & 2.16 & 0.10 & 0.43 & 4.80 & 8.48 & 43.39 \\
\hline & B3t & $57-96$ & 76.84 & $\begin{array}{l}11.9 \\
4\end{array}$ & $\begin{array}{l}11.2 \\
2\end{array}$ & LS & 4.62 & 3.75 & 0.10 & 70.66 & 0.08 & 2.40 & 1.00 & 0.07 & 5.40 & 8.99 & 38.26 \\
\hline & & Mean & 83.84 & 8.44 & 7.72 & & 4.60 & 2.94 & 0.08 & 42.91 & 0.09 & 2.64 & 1.03 & 0.17 & 4.79 & 8.66 & 44.73 \\
\hline & FP & Mean & 84.38 & 7.68 & 7.94 & & 4.88 & 2.02 & 0.06 & 20.66 & 0.09 & 2.89 & 1.23 & 0.10 & 9.69 & 13.23 & 43.72 \\
\hline & & $\begin{array}{l}\text { Keys } \\
\mathrm{S}=\text { San } \\
\text { Org. M } \\
\text { H D }\end{array}$ & $\begin{array}{l}\text { Org } \\
\text { Horiz }\end{array}$ & 1 & $\begin{array}{c}\text { BS } \\
\text { ation }\end{array}$ & 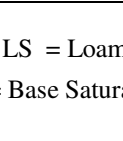 & Sand & & & & & & & & & & \\
\hline
\end{tabular}


Fertility Assessment of Some Inland Depression and Floodplain (Wetland) Soils in Akwa Ibom State

\section{Gleying (g)}

The study revealed that water logging is one of the constraints to crop production in wetlands soils of Akwa Ibom State. The soils are poorly drained in most parts of the year. This is a key feature that tends to limit or hinder all year round utilization of wetland soils for agricultural production (Ojanuga and Lekwa, 1984). Apart from affecting the workability of the soils, water logging pose environmental hazard by emitting greenhouse gases like methane and nitrous oxide into the atmosphere. (Sanchez et al, 1982

However, water logging is a positive attribute for growing swamp rice. This is an indication that if the soils are well managed, they could be used to produce paddy rice. Also another advantage of water logging especially as caused by flooding is that it raises the content of available phosphorus (Ponnamperuma, 1972).

For these soils to be used efficiently, field drains should be constructed to remove the standing water. Moreso, elevated beds and mounds should be used in planting. Farmers should plant crops, which could adapt to water- logging condition.

\section{Acidic reaction $(h)$}

Akwa Ibom State is one of the coastal states of the country which is noted for high rainfall. The high rainfall makes the soil fragile and susceptible to erosion and leaching (Uniuyo Consult Ltd, 2003). This high erosion and leaching wash away the more mobile basic cations leaving behind acidic and sesquioxides which contribute to the acidic condition. This condition could be brought under control by the application of lime and minimizing the use of acid forming fertilizers.

Nevertheless, wetland soils have high inherent fertility and it has been observed that even with low $\mathrm{pH}$, crop can still do well if it has high organic matter content (Davies et al, 1993 and Edem et al, 1998). Application of cattle manure can reduce soils $\mathrm{pH}$ as Whalen et al, (2000) noted that cattle manure can in a short term increase the $\mathrm{pH}$ and quantity of plant available $\mathrm{P}$ and $\mathrm{K}$ in acid soils. Bickelhaupt (1989) found that the application of composted lime - treated horse manure to a slightly acidic soil $\mathrm{pH}$ (5.7) increased soil $\mathrm{pH}$ to between 6.7 and 7.3, the effect was undiminished for 12 years after manure application

\section{Low potassium reserve $(\mathbf{k})$}

Low $\mathrm{K}$ reserve was another problem of the soils studied. Similar observation was made by Udo, (2001) that wetland soils of the area have low $\mathrm{k}$ reserve as one of the fertility indicators. Though $\mathrm{K}$ is found comparatively high levels in most mineral soils, the quantity of $\mathrm{K}$ held in an easily exchangeable condition at any one time is very small (Brady and Weil, 1990). The low availability of exchangeable K and other basic cations may be caused by low pH. Whalen et al., (2000) opined that soil pH affects nutrient solubility, and influences the sorption or precipitation of nutrient with $\mathrm{Al}$ and Fe. Also, Hue (1992) reported that increasing the $\mathrm{pH}$ of acidic soils improve plant availability of macronutrients while reducing the solubility of element such as $\mathrm{Al}$ and $\mathrm{Mn}$ (O’ Hollarans et al, 1997).

Apart from losses from plant removal which may be as great as $400 \mathrm{~kg} / \mathrm{ha}$ annually, the annual loss of available $\mathrm{K}$ by leaching and erosion can exceed those of nitrogen and phosphorus ( Brady and Weil,1999).

\section{Sandy (S)}

The study also revealed that the soils studied were generally sandy. The sandy nature of the soils may be due to excessive rainfalls experienced in the region which cause erosion (Uniuyo Consult Ltd, 2003). This also explain while the soils have low $\mathrm{K}$ reserves as typical sandy soils (with small surface areas) have low ion exchange capacity, which determine the quantity of ions that a soil can retain against leaching (Edem, 2007). The ion exchange capacity is located on soil colloids (soil organic matter and clay surfaces). This greatly determines the capacity of the soil to hold and exchange ions (both anions and cations) and the degree of saturation of different ions. Increasing the organic matter content of the soils will enhance the nutrients retention capacity of these soils. 
Udo Bassey, U., Utip, Kufre, E.. Inyang, Monday, T and. Idungafa Monday, A.

Table 3: Fertility Capability Classification (FCC) Units of the Pedons in the Studied Soils

\begin{tabular}{|c|c|c|c|c|c|c|c|c|c|c|c|}
\hline \multirow[t]{2}{*}{ Pedon } & \multirow[t]{2}{*}{ Top Soil } & \multirow[t]{2}{*}{ Sub Soil } & \multicolumn{8}{|c|}{ Condition modifiers } & \multirow[t]{2}{*}{ FCC Units } \\
\hline & & & $\mathbf{g}$ & d & $\mathbf{k}$ & $\mathbf{e}$ & $\mathbf{a}$ & $\mathbf{h}$ & $\mathbf{b}$ & $\mathbf{n}$ & \\
\hline Ikg & $\mathrm{S}$ & $\mathrm{L}$ & + & - & + & - & - & + & - & - & SLgkh \\
\hline Ikd & $\mathrm{S}$ & $\mathrm{L}$ & + & - & + & - & - & + & - & - & Skggh \\
\hline $\mathrm{Bku}$ & $\mathrm{L}$ & $\mathrm{L}$ & + & - & + & - & - & + & - & - & Lgkh \\
\hline Ibk & $\mathrm{S}$ & $\mathrm{S}$ & + & - & + & - & - & + & - & - & Sgkh \\
\hline Usg & $\mathrm{S}$ & $\mathrm{S}$ & + & - & + & - & - & + & - & - & Sgkh \\
\hline Iwk & $\mathrm{S}$ & $\mathrm{S}$ & + & - & + & - & - & + & - & - & Sgkh \\
\hline $\begin{array}{l}\text { Keys: } \\
L=\text { Loamy, } \\
E=\text { low cation } \\
B=\text { basic reac }\end{array}$ & e, & $\begin{array}{l}\mathrm{S}=\text { Sandy } \\
\mathrm{k}=\text { low nu } \\
\mathrm{g}=\text { gleying }\end{array}$ & & & & & & $\begin{array}{l}\mathrm{h}= \\
\mathrm{n}= \\
\mathrm{d}=\end{array}$ & $\begin{array}{l}\text { Icidic } \\
\text { Iatric } \\
\text { Iry, }\end{array}$ & reaction, & \\
\hline
\end{tabular}

\section{CONCLUSION AND RECOMMENDATIONS}

Fertility constraints of the soils were assessed using the Fertility Capability Classification (FCC) system. The study revealed that general fertility constraints of the soils were gleying (g) acidic reaction (h) and low potassium reserve $(\mathrm{k})$. The soils were also deficient texturally as they were generally sandy. However with efficient soil management through lime, NPK fertilizers and organic manure (e.g cattle manure) application, the soils will support arable crop production. Making of mounds, field drains and planting of water logged resistant plants like paddy rice could also help to increase the productivity of the soils.

\section{REFERENCES}

Bickelhaupt, D. H. (1989). The long-term effect of a single application of house manure on soil pH. Tree Planters' Note 40:31-33.

Bouyoucous, G. A. (1951) Determination of particle size in soils. Agronomy Journal 42:438-439

Bray, R. A. and Kurtz, C. L. (1945) Determination of total, organic and available forms of phosphorus in Soils. Journal of Soil Science 59:45 -49.

Dar, W. D. (2004). Macro-benefits from micronutrients from grey to green revolution in Agriculture. A paper presented in IFA International Symposium on micronutrients on $23-26$. February 2004, New Delhi, India.

Davies, D. B, Eagle, D. J. and Finney, J. B. (1993). Soil management. Farming Press Books and Videos, Wharfedale Road, UK.
Day, P. R. (1965) Hydrometer method of particle size analysis. In C. A. Black (ed) Methods of soil analysis. Am. Soc. of Agron., Madison Wisconsin.

Brady, N. C. and Weil, R. R.(1999).The nature and properties of soils,(12 $2^{\text {th }}$ Edition). Published by Prentice Hall' Upper Saddle River, New Jersy.

Edem, S. O., Effiong, G. S. and Umoh, G. S. (1998) Wetlands of Akwa Ibom State: Utilization and present land use practices, Nigeria J. Agric. Tech. 7: 13-24.

Edem. S. O. (2007) Soil: The Dynamic System. Published by Minder International Publishers, Uyo, Nigeria.

Eshiet, E. T. (1994) The Wetlands of Nigeria: Distribution, characterization and traditional land use practices 21st Annual Conf. of Soil Science Society of Nigeria, Uyo.

Guthrie, R. L. (1985), Characterizing and classifying wetland soils in relation to food production. In wetland soils: Characterization, classification and utilization. International Rice Research Institute (IRRI) Los Banos, Phlipines pp. 11-22.

Hue, N. V. (1992) Correcting Soil acidity of a highly weathered ultisol with chicken manure and sewage sludge. Commun. Soil Sci. Plant Anal. 23: 241-264

Jackson, M. L. (1962) Soil Chemical Analysis. Constable and Co. Ltd London.

Jager de A., Nandwa, S. M. and Okoth, P. E. (1998) Monitoring nutrient flows and economic performance in African farming systems (NUTMON); I Concepts and methodologies. Agric. Ecosyst and Environ. 71:31 - 48. 
Juo, A.S.R. (1975) Selected methods of soil and plant analysis. IITA, Ibadan, Nigeria.

Katyal, J. C. (2004) Role of micronutrients in ensuring optimum use of macronutrients. IFA International Symposium on Micronutrients, 23-25 Feb, 2004, New Delhi, India

Lin, C. (1989) Fertility capability classification of Taiwan Soils. Classification and management of rice growing soils. FIFTC Book series, No. 39

O’ Hollorans, J., Munoz, M. A. and Marquez, P. E. (1997) Chicken manure as an amendment to correct soil acidity and fertility. J. Agric. Univ. P. R. 81:1-8.

Ogban P. I. and Ibia T. O. (1998) Characteristics and crop production Potentials of wetland Soils from South Eastern Nigeria. Nig. J. Agric. Tech.. 7: $78-84$.

Ojanugu, A. G. and Lewka, G. (1984) Distribution, classification and uses of wetlands. A Paper presented in the 12th Annual Conference of Soil Science Society of Nigeria, Port Harcourt, Nigeria.

Onyekwere, I. N. Akpanidiok, A. U, Amalu, U. C., Asawalam, D. O and Eze, P. C. (2001) Constraints and opportunities in agricultural utilization of some wetland soils in Akwa Ibom State. Proc. of $27^{\text {th }}$ Annual Conf. of Soil Science Society of Nigeria, pp 139 - 146.

Pennamperuma, F. N. (1972) The chemistry of submerged soils. Adv. Agron. 24:29-40.

Sanchez, P. A.; Couto, W and Boul, S. W. (1982). The fertility capability classification system: Interpretation, applicability and modification. Geoderma 27: 283 - 309

Sanchez, P. A. and Boul, S. W. (1985). Agronomic Taxonomy, for wetland soils. In Wetland Soils: characterization, classification and utilization (S. J. Banta and C. V. Mendoza, eds). International
Rice Research Institute, Los Banos, Philippines, pp. 207 - 227.

Spiertz, H and Rabbinge, R. (1999) Agriculture and resource management: Future needs in Europe and developing countries. IFA Agricultural conference on managing plant nutrition, 29 June - 2 July, 1999. Barcelona, Spain

Udo, B. U., Edem, S. O., Udom, G. N. and Ndaeyo, N. U. (2008) Chemical characteristics of wetland soils in Akwa Ibom State, Nigeria J. Agric. Tech. 13: 53-64.

Udo, B. U. (2007) Characteristics of inland valley and floodplain soils in Akwa Ibom State. M. Sc. Thesis, Dept of Soil Science, University of Uyo, Uyo, Nigeria.

Udo, E. J. (2001) Nutrient status and agricultural potential of wetland soils. Proc. $27^{\text {th }}$ Annual Conf. of Soil Science Society of Nigeria held from November 5 - 9, 2001 in University of Calaber, Calabar,pp 112118.

Udo, E. J. and Ogunwale, J. A. (1986). Laboratory manual for the analysis of soil, plant and water samples, Dept. of Agronomy, University of Ibadan, Ibadan, Nigeria.

Uniuyo Consult Ltd (2003) Soil Survey Report: Soil potentials of Akwa Ibom State (a) Soils of the Coastal Zone. Prepared by University of Uyo Consult Ltd, Uyo.

Van, K. H. and Breman, H. (1990) Agricultural development in the West African Sahelian region: A cure against land hunger? Agric. Ecosyst. Environ 32:177-197

Walkey, A and Black, I. A. (1935) Organic Carbon, In: C. A. Black, (Ed) Method of Soil Analysis Part 2. American Society of Agronomy 9: 1372 - 1376.

Whalen, J. K.; Chang, C; Clayton, G. Wand Carefoot (2000). Cattle manure amendment can increase $\mathrm{pH}$ of acid soils. Soil Sci. Soc. Am. J. 64: 962 -966. 